\title{
Varicella in Adult Foreigners at a Referral Hospital, Central Tokyo, Japan, 2012-2016
}

Saho Takaya, Satoshi Kutsuna, Yuichi Katanami, Kei Yamamoto, Nozomi Takeshita, Kayoko Hayakawa, Yasuyuki Kato, Shuzo Kanagawa, Norio Ohmagari

We report a case series of varicella among adult foreigners at a referral hospital in central Tokyo, Japan, during 2012-2016. This series highlights differences in varicella vaccination schedules by country and epidemiology by climate and identifies immigrants and international students as high-risk populations for varicella.

$\mathrm{V}$ Taricella is a benign disease with fever and rash caused by primary infection with varicella zoster virus (VZV) (1). Varicella is usually self-limiting but can sometimes be life-threatening, especially in adults (1). The World Health Organization estimates that 140 million varicella cases and 4,200 related deaths occur each year (1). In Japan, 1 million persons, primarily young children, have varicella every year. Of these patients, 4,000 require hospitalization, and adults make up $\approx 60 \%$ of this population (2).

Varicella vaccine is a live attenuated vaccine and is effective against varicella in healthy children (1). One dose of varicella vaccine reduces the number of varicella cases but can also reduce opportunities for exposure to the virus in the community and result in breakthrough varicella. Therefore, many industrialized countries now recommend 2 doses of varicella vaccine (2). In Japan, the 2-dose varicella vaccination became part of the childhood immunization schedule in October 2014; the number of varicella cases has drastically decreased since implementation (3).

We report cases of varicella in adult foreigners who were given a diagnosis at the National Center for Global Health and Medicine (NCGM) Medical Center in central Tokyo, Japan. These cases highlight major health issues, including differences in varicella vaccination programs in countries and VZV epidemiology in temperate and tropical regions, and identify

Author affiliation: National Center for Global Health and Medicine, Tokyo, Japan

DOI: https://doi.org/10.3201/eid2601.170565 immigrants and international students as high-risk populations for varicella.

\section{The Study}

We reviewed 22 varicella cases in adult foreigners diagnosed during January 2012-December 2016 at the NCGM. During the same period, 7 cases of varicella were diagnosed in Japanese adults at the NCGM. We compiled basic demographic information for the patients (Table). Eleven case-patients were from Vietnam, 5 from China, and 1 each from 6 other countries (Cambodia, New Zealand, Belgium, Italy, Uzbekistan, and Nepal). Among 21 patients who resided in central Tokyo, 18 were international students. Fourteen patients were male, and the median age was 19 years (range 18-35 years).

The patients sought medical care on median day 2 of illness (range days 1-5). Most diagnoses of varicella were made clinically; for some case-patients, varicella was confirmed by serologic testing or PCR or antigen detection testing of skin lesions. Twenty patients received antiviral therapy (acyclovir or valacyclovir). Five case-patients were hospitalized because of severe malaise and for infection control to prevent secondary cases.

Nine patients from Vietnam and 1 from China (case-patients 3-12) were students at the same language school who lived together in the school dormitories. During this outbreak, varicella developed in 9 students during a 2-month period after the index case (case 3 ). Information about previous vaccination and past infection could not be obtained for most patients in this outbreak because of their inability to communicate in Japanese or English and our inability to organize translation in the first language of the patients immediately at their visits. Overall, we found that there were 81 international students in 3 dormitories: $30(37.0 \%)$ reported previous varicella and $6(7.4 \%)$ claimed to have been 
Table. Characteristics for 22 case-patients (adult foreigners) with varicella, National Center for Global Health and Medicine, Tokyo, Japan, 2012-2016*

\begin{tabular}{|c|c|c|c|c|c|c|c|c|c|}
\hline $\begin{array}{l}\text { Case- } \\
\text { patient no. }\end{array}$ & $\begin{array}{c}\text { Time of } \\
\text { onset }\end{array}$ & $\begin{array}{c}\text { Days after } \\
\text { onset of index } \\
\text { case }\end{array}$ & $\begin{array}{l}\text { Age, } \\
\text { y/sex }\end{array}$ & $\begin{array}{c}\text { Country of } \\
\text { origin }\end{array}$ & $\begin{array}{l}\text { Status or } \\
\text { occupation }\end{array}$ & $\begin{array}{c}\text { Exposure } \\
\text { source }\end{array}$ & $\begin{array}{c}\text { History } \\
\text { of } \\
\text { varicella }\end{array}$ & $\begin{array}{c}\text { Previous } \\
\text { varicella } \\
\text { vaccination }\end{array}$ & $\begin{array}{c}\text { Hospitalization } \\
\text { (reason) }\end{array}$ \\
\hline 1 & $2012 \mathrm{Apr}$ & Not applicable & $19 / \mathrm{M}$ & Cambodia & Student & Sibling & NA & NA & $\begin{array}{c}\text { Yes (infection } \\
\text { control) }\end{array}$ \\
\hline 2 & 2012 Jul & Not applicable & $32 / F$ & China & Housewife & Own child & No & NA & No \\
\hline 3 & $2014 \mathrm{Apr}$ & Index case & $18 / \mathrm{M}$ & Vietnam & Student & UNK & No & UNK & No \\
\hline 4 & $2014 \mathrm{Apr}$ & 15 & $18 / \mathrm{M}$ & Vietnam & Student & $\begin{array}{l}\text { School } \\
\text { dormitory }\end{array}$ & No & UNK & No \\
\hline 5 & $2014 \mathrm{Apr}$ & 15 & $18 / \mathrm{M}$ & Vietnam & Student & $\begin{array}{l}\text { School } \\
\text { dormitory }\end{array}$ & NA & NA & No \\
\hline 6 & 2014 May & 19 & $18 / \mathrm{M}$ & Vietnam & Student & $\begin{array}{l}\text { School } \\
\text { dormitory }\end{array}$ & NA & NA & No \\
\hline 7 & 2014 May & 35 & 19/M & Vietnam & Student & School & NA & NA & No \\
\hline 8 & 2014 May & 41 & $19 / F$ & Vietnam & Student & $\begin{array}{l}\text { School } \\
\text { dormitory }\end{array}$ & NA & UNK & No \\
\hline 9 & 2014 May & 42 & $18 / F$ & Vietnam & Student & $\begin{array}{l}\text { School } \\
\text { dormitory }\end{array}$ & NA & UNK & No \\
\hline 10 & 2014 Jun & 52 & $19 / \mathrm{M}$ & Vietnam & Student & School & NA & NA & No \\
\hline 11 & 2014 Jun & 55 & $23 / \mathrm{M}$ & Vietnam & Student & $\begin{array}{l}\text { School } \\
\text { dormitory }\end{array}$ & NA & NA & No \\
\hline 12 & 2014 Jun & 56 & $19 / \mathrm{M}$ & China & Student & $\begin{array}{l}\text { School } \\
\text { dormitory }\end{array}$ & NA & NA & No \\
\hline 13 & 2016 Mar & Not applicable & $18 / F$ & Vietnam & Student & UNK & No & No & No \\
\hline 14 & 2016 Mar & Not applicable & $19 / F$ & $\begin{array}{c}\text { New } \\
\text { Zealand }\end{array}$ & Student & UNK & No & No & Yes (malaise) \\
\hline 15 & $2016 \mathrm{Apr}$ & Index case & $35 / F$ & China & Housewife & UNK & No & No & Yes (malaise) \\
\hline 16 & $2016 \mathrm{Apr}$ & 12 & $34 / \mathrm{M}$ & China & Unemployed & $\begin{array}{l}\text { Patient } 15 \\
\text { (wife) }\end{array}$ & No & Yes & No \\
\hline 17 & 2016 May & Not applicable & $19 / \mathrm{M}$ & China & Student & UNK & No & No & $\begin{array}{c}\text { Yes (malaise, } \\
\text { headache) }\end{array}$ \\
\hline 18 & 2016 May & Not applicable & $33 / \mathrm{M}$ & Belgium & Tourist & UNK & UNK & NA & No \\
\hline 19 & $2016 \mathrm{Jul}$ & Not applicable & $21 / F$ & Italy & Student & UNK & No & No & $\begin{array}{l}\text { Yes (infection } \\
\text { control) }\end{array}$ \\
\hline 20 & 2016 Aug & Not applicable & $20 / \mathrm{M}$ & Uzbekistan & Student & UNK & Yes & No & No \\
\hline 21 & 2016 Sep & Not applicable & $23 / \mathrm{M}$ & Vietnam & Student & UNK & No & UNK & No \\
\hline 22 & 2016 Oct & Not applicable & $25 / \mathrm{F}$ & Nepal & Sales clerk & UNK & No & No & No \\
\hline
\end{tabular}

vaccinated at least once. Although we contacted the school to provide postexposure prophylaxis, none of 41 students without previous VZV infection had received it.

\section{Conclusions}

Japan has $>2$ million foreign residents; most are from China (30\%), South Korea (20\%), and the Philippines $(10 \%)(4)$. However, Japan does not have any vaccination requirements for foreign residents. Because varicella is not a target of the World Health Organization Expanded Program on Immunization, the vaccine is not included in the national immunization schedules of many countries.

In China, from which Japan receives most of its immigrants and tourists, varicella vaccine was approved in the late 1990s and has been given on a voluntary basis (5). Although $80 \%$ of children in kindergartens and primary schools in Beijing were reported to have received the varicella vaccine, most had only received 1 dose, and breakthrough varicella has become a public health concern (5). In South Korea, the single-dose varicella vaccination was included in the national immunization program in 2005 and is recommended for 12-15-month-old children (6). Despite high use of the vaccine $(>95 \%)$, varicella outbreaks continuously occur (6). The varicella vaccine has not been introduced into the national vaccination program of the Philippines (7).

The epidemiology of varicella differs between temperate and tropical regions. In temperate areas, most of the population contracts VZV before adolescence. In tropical areas, childhood varicella is much less common, and many persons stay susceptible to VZV until adulthood $(1,8)$. This difference is attributed to changes in VZV transmissibility by temperature and humidity, population density, and sociologic factors, such as nursery school attendance (8).

Previous research has shown immigrants and refugees to be at high risk for varicella. A study in 
Denmark during the 1980s investigated an epidemic of varicella among refugees during a preasylum phase (9). The study showed that $44 \%$ of Tamil refugees from Sri Lanka had varicella infections within 1 week to 5 months after arrival in Denmark. Considering that many immigrants contracted varicella shortly after their arrival, it was deemed necessary to check VZV immunity for immigrants before they entered that country, rather than after entry.

In an outbreak study of 18 varicella cases among Mexican-born workers in Alabama, USA (10), Mexican-born workers were 5 times more likely to be susceptible to VZV than US-born workers. Although postexposure prophylaxis vaccine was provided to susceptible workers, a second dose was not administered to many of those who needed it. This finding shows the difficulty in reaching these populations because of their lack of stable access to healthcare. Faced with a rapidly aging population, Japan has also been accepting nurses and caregivers from countries in Southeast Asia as medical personnel in healthcare facilities and nursing homes (11). Thus, nosocomial infection with $\mathrm{VZV}$ is also a matter of concern.

Japan had 208,000 international students during 2015 (12). More than $90 \%$ of these students were from countries in Asia; most were from China (45\%), Vietnam (19\%), and Nepal (8\%). The demographics of the case-patients in our study were consistent with these data. In general, colleges are suitable environments for communicable disease outbreaks because of highly dense interactions among students and staff, crowded living conditions, and an influx of students from many countries (13). Because $10 \%-20 \%$ of persons in Japan $15-30$ years of age are susceptible to VZV (14), varicella outbreaks among international students might spread into the local student population. Despite these facts, Japan does not have any regulations or recommendations regarding the health of international students. In the United States, the American College Health Association strongly recommends institutional prematriculation immunizations (15). These guidelines recommend that all college students should have 2 doses of varicella vaccine unless they have other evidence of VZV immunity.

This varicella case series occurred in multifactorial contexts. However, little is known about the immunity against VZV among foreign residents in Japan. Educational institutions that receive international students need to consider varicella as a major preventable health issue among their students. Healthcare providers for immigrants and international students should also be aware of the risk for varicella and should verify VZV immunity or varicella vaccination status for students.

This study was supported by a grant (27-6001) from the National Center for Global Health and Medicine, Tokyo, Japan.

\section{About the Author}

Dr. Takaya is a physician at the Disease Control and Prevention Center, National Center for Global Health and Medicine, Tokyo, Japan. Her primary research interest is tropical medicine.

\section{References}

1. World Health Organization. Varicella and herpes zoster vaccines: WHO position paper; 2014 [cited 2016 Jun 2]. http://www.who.int/immunization/position_papers/ WHO_pp_varicella_herpes_zoster_june2014_presentation.pdf

2. National Institute of Infectious Diseases. Japan. Varicella vaccine fact sheet; 2010 [cited 2016 Nov 4]. http:/ / www.mhlw.go.jp/stf2/shingi2/2r9852000000bx23-att/ 2r9852000000bxqx.pdf

3. National Institute of Infectious Diseases. Japan. Varicella situation update after the introduction of two doses of varicella vaccine into the routine vaccination, from Infectious Diseases Weekly Report (IDWR), a third report [cited 2018 Apr 20]. https:/ / www.niid.go.jp/niid/ja/ varicella-m/varicella-idwrs/7620-varicella-20171020.html

4. Japanese Ministry of Justice. The number of foreign residents in Japan as of December 2015-2016 [cited 2016 Dec 7]. http://www.moj.go.jp/nyuukokukanri/kouhou/ nyuukokukanri04_00057.html

5. Zhang X, Yu Y, Zhang J, Huang S, Wang Z, Zhang J, et al. The epidemiology of varicella cases among children in Beijing's Fengtai District from 2008 to 2012. Vaccine. 2014; 32:3569-72. https:/ / doi.org/10.1016/j.vaccine.2014.04.069

6. Oh SH, Choi EH, Shin SH, Kim YK, Chang JK, Choi KM, et al. Varicella and varicella vaccination in South Korea. Clin Vaccine Immunol. 2014;21:762-8. https:/ / doi.org/10.1128/ CVI.00645-13

7. World Health Organization. WHO vaccine-preventable diseases: monitoring system; 2017 global summary [cited 2018 Apr 20]. http://apps.who.int/immunization_ monitoring/globalsummary

8. Lolekha S, Tanthiphabha W, Sornchai P, Kosuwan P, Sutra S, Warachit B, et al. Effect of climatic factors and population density on varicella zoster virus epidemiology within a tropical country. Am J Trop Med Hyg. 2001;64: 131-6. https://doi.org/10.4269/ajtmh.2001.64.131

9. Kjersem $\mathrm{H}$, Jepsen $\mathrm{S}$. Varicella among immigrants from the tropics, a health problem. Scand J Soc Med. 1990;18:171-4. https://doi.org/10.1177/140349489001800303

10. Danovaro-Holliday MC, Gordon ER, Jumaan AO, Woernle C, Judy RH, Schmid DS, et al. High rate of varicella complications among Mexican-born adults in Alabama. Clin Infect Dis. 2004;39:1633-9. https:// doi.org/10.1086/425613

11. Ministry of Health, Labour, and Welfare. Acceptance of foreign nurses and carers from Indonesia, the Philippines, and Vietnam [cited 2016 Dec 5]. http://www.mhlw.go.jp/ stf/seisakunitsuite/bunya/koyou_roudou/koyou/ gaikokujin/other22/index 
12. Japan Student Services Organization. International students in Japan; 2015 [cited 2016 Nov 5]. http:/ / www.jasso.go.jp/ en/about/statistics/intl_student/data2015.html

13. Jewett A, Bell T, Cohen NJ, Buckley K, Leino EV, Even S, et al. US college and university student health screening requirements for tuberculosis and vaccine-preventable diseases, 2012. J Am Coll Health. 2016;64:409-15. https:/ / doi.org/10.1080/07448481.2015.1117465

14. National Institute of Infectious Diseases. Japan. Immunity status for varicella-zoster virus between 2014 and 2016 [cited 2018 Apr 20]. https://www.niid.go.jp/niid/ja/ y-graphs/7200-varicella-yosoku-year2016.html
15. American College Health Association. ACHA guidelines: recommendations for institutional prematriculation immunizations; 2014 [cited 2018 Apr 20]. https:/ / www. acha.org/documents/resources/guidelines/ACHA_RIPI_ April_2014.pdf

Address for correspondence: Satoshi Kutsuna, Disease Control and Prevention Center, National Center for Global Health and Medicine, 1-21-1, Toyama, Shinjuku, Tokyo 162-8655, Japan; email: sonare.since1192@gmail.com

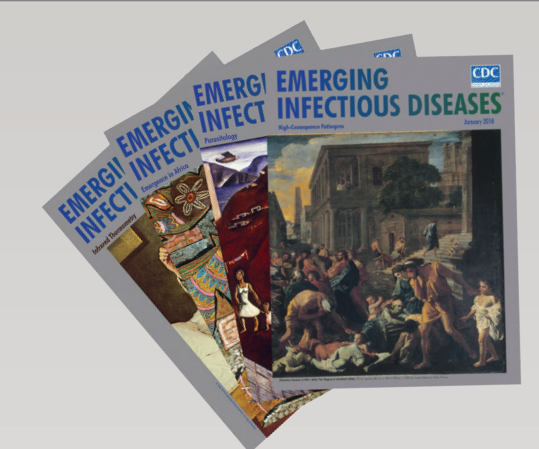

- Zika Virus Testing and Outcomes during Pregnancy, Florida, USA, 2016

- Sensitivity and Specificity of Suspected Case Definition Used during West Africa Ebola Epidemic

- Nipah Virus Contamination of Hospital Surfaces during Outbreaks, Bangladesh, 2013-2014

- Detection and Circulation of a Novel Rabbit Hemorrhagic Disease Virus, Australia

- Drug-Resistant Polymorphisms and Copy Numbers in Plasmodium falciparum, Mozambique, 2015

- Increased Severity and Spread of Mycobacterium ulcerans, Southeastern Australia

- Emergence of Vaccine-Derived Polioviruses during Ebola Virus Disease Outbreak, Guinea, 2014-2015

- Characterization of a Feline Influenza A(H7N2) Virus

- Japanese Encephalitis Virus Transmitted Via Blood Transfusion, Hong Kong, China

- Changing Geographic Patterns and Risk Factors for Avian Influenza A(H7N9) Infections in Humans, China

- Pneumonic Plague in Johannesburg, South Africa, 1904

- Dangers of Noncritical Use of Historical Plague Databases

- Recognition of Azole-Resistant Aspergillosis by Physicians Specializing in Infectious Diseases, United States

- Melioidosis, Singapore, 2003-2014

- Serologic Evidence of Fruit Bat Exposure to Filoviruses, Singapore, 2011-2016

\section{January 2018}

\section{-Consequence Pathogens}

- Expected Duration of Adverse Pregnancy Outcomes after Zika Epidemic

- Seroprevalence of Jamestown Canyon Virus among Deer and Humans, Nova Scotia, Canada

- Postmortem Findings for a Patient with Guillain-Barré Syndrome and Zika Virus Infection

- Rodent Abundance and Hantavirus Infection in Protected Area, East-Central Argentina

- Two-Center Evaluation of Disinfectant Efficacy against Ebola Virus in Clinical and Laboratory Matrices

- Phylogeny and Immunoreactivity of Human Norovirus GII.P16-GII.2, Japan, Winter 2016-17

- Mammalian Pathogenesis and Transmission of Avian Influenza A(H7N9) Viruses, Tennessee, USA, 2017

- Whole Genome Analysis of Recurrent Staphylococcus aureus t571/ST398 Infection in Farmer, lowa, USA

- Visceral Leishmaniasis in Traveler to Guyana Caused by Leishmania siamensis, London

- Investigation of Canine-Mediated Human Rabies Death, Haiti, 2015

- Epidemiology of Cutaneous Leishmaniasis Outbreak, Waziristan, Pakistan

- Ocular Vaccinia Infection in Dairy Worker, Brazil

- Estimation of Undiagnosed Naegleria fowleri Primary Amebic Meningoencephalitis, United States

- Leprosy in Nonimmigrant Canadian Man without Travel 